\title{
Surveillance: Developing a network for small animal disease surveillance
}

DOI:

10.1136/vr.c5180

Link to publication record in Manchester Research Explorer

\section{Citation for published version (APA):}

Radford, A., Tierney, A., Coyne, K. P., Gaskell, R. M., Noble, P. J., Dawson, S., Setzkorn, C., Jones, P. H., Buchan, I. E., Newton, J. R., \& Bryan, J. G. E. (2010). Surveillance: Developing a network for small animal disease surveillance. Veterinary Record, 167(13), 472-474. https://doi.org/10.1136/vr.c5180

\section{Published in:}

Veterinary Record

\section{Citing this paper}

Please note that where the full-text provided on Manchester Research Explorer is the Author Accepted Manuscript or Proof version this may differ from the final Published version. If citing, it is advised that you check and use the publisher's definitive version.

\section{General rights}

Copyright and moral rights for the publications made accessible in the Research Explorer are retained by the authors and/or other copyright owners and it is a condition of accessing publications that users recognise and abide by the legal requirements associated with these rights.

\section{Takedown policy}

If you believe that this document breaches copyright please refer to the University of Manchester's Takedown Procedures [http://man.ac.uk/04Y6Bo] or contact uml.scholarlycommunications@manchester.ac.uk providing relevant details, so we can investigate your claim.

\section{OPEN ACCESS}




\section{veterinary Developing a network for small animal disease surveillance}

A. Radford, Á. Tierney, K. P. Coyne, et al.

Veterinary Record 2010 167: 472-474

doi: $10.1136 / v r . c 5180$

Updated information and services can be found at:

http://veterinaryrecord.bmj.com/content/167/13/472.full.html

These include:

References This article cites 3 articles, 1 of which can be accessed free at: http://veterinaryrecord.bmj.com/content/167/13/472.full.html\#ref-list-1

Email alerting Receive free email alerts when new articles cite this article. Sign up in the service box at the top right corner of the online article.

Notes

To request permissions go to:

http://group.bmj.com/group/rights-licensing/permissions

To order reprints go to:

http://journals.bmj.com/cgi/reprintform

To subscribe to BMJ go to:

http://journals.bmj.com/cgi/ep 


\title{
Feature
}

SURVEILLANCE

\section{Developing a network for small animal disease surveillance}

\author{
The Small Animal Veterinary Surveillance Network (SAVSNET) was launched in 2008 to address the lack of structured \\ national surveillance of companion animals. Two years on, Alan Radford, Áine Tierney and other members of the \\ SAVSNET team discuss progress to date
}

SURVEILLANCE involves monitoring disease, infection or other health indices in a defined population, such that action can be taken when necessary. In the UK, this is currently performed for livestock with government funding through subsidised diagnostics at the Veterinary Laboratories Agency (VLA 2008). For equine disease, a more recent initiative established by the Animal Health Trust has sought to mimic this surveillance of laboratory data in a more devolved sector using results supplied by commercial diagnostic laboratories (Defral AHT/BEVA 2010).

However, there is currently limited structured and coordinated small/companion animal disease surveillance (CAWC 2008). This is in stark contrast to the size of the small animal population; it is estimated that there were about 10.5 million dogs and 10.3 million cats in the UK in 2007, with 43 to 52 per cent of households owning at least one pet (Westgarth and others 2007, Murray and others 2010). Those surveillance activities that have been developed are limited to focused initiatives including SARSS (the Suspected Adverse Reaction Surveillance Scheme), run by the Veterinary Medicines Directorate (VMD 2010), and DACTARI (Dog and Cat Travel and Risk Information), run by Defra to monitor infectious diseases that are considered exotic to the UK (Defra 2010). More recent initiatives include CICADA (Computerbased Investigation of Companion Animal Disease Awareness), a voluntary reporting

\footnotetext{
A. Radford, Á. Tierney, K. P. Coyne, R. M. Gaskell, P. J. Noble, S. Dawson, Faculty of Health and Life Sciences, C. Setzkorn, P. H. Jones, National Centre for Zoonosis Research, Leahurst Campus, University of Liverpool, Chester High Road, Neston, Cheshire CH64 7TE

I. E. Buchan, Northwest Institute for
}

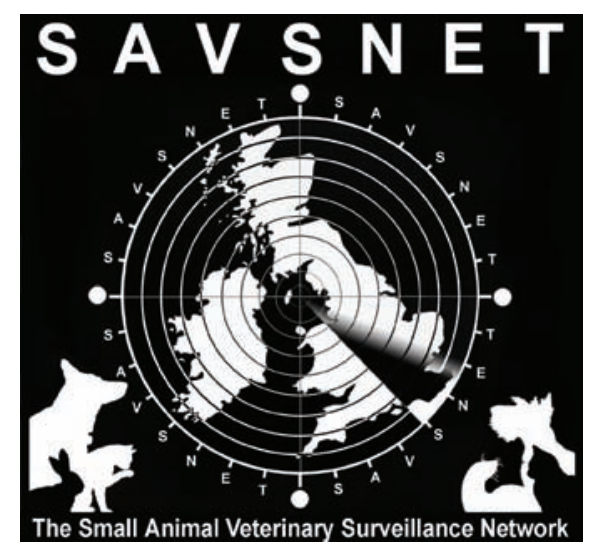

system run by Intervet/Schering-Plough Animal Health where vets in practice can $\log$ onto a website to report the diseases they are encountering (CICADA 2010), VeNom (VEterinary NOMenclature), a clinical coding system developed by the Royal Veterinary College, Glasgow veterinary school and the PDSA (VeNom 2010), and CEVM (Centre of Evidence-Based Veterinary Medicine) at the University of Nottingham.

This lack of structured national surveillance of companion animals means that disease burdens are generally unknown, and new diseases may be difficult to identify quickly; for example, H3N8 in dogs (Crawford and others 2005) or H1N1 in cats (ProMED Mail 2009). It also means there is an inability to develop clear goals and strategies to reduce disease

BioHealth Informatics (NIBHI), 1.311 Jean MacFarlane Building, Community Based Medicine, University of Manchester, Oxford Road, Manchester M13 9PL J. R. Newton, Epidemiology and Disease Surveillance, Animal Health Trust, Newmarket, Suffolk CB8 7UU J. G. E. Bryan, Vet Solutions, Papermill Wynd, Edinburgh EH7 4OL incidence, or to evaluate their success. Since approximately 75 per cent of new and emerging diseases are zoonoses (Taylor and others 2001), this lack of surveillance also has implications for human health.

The Small Animal Veterinary Surveillance Network (SAVSNET) was launched in September 2008 as a collaborative project between the University of Liverpool, Vet Solutions and the Animal Health Trust to address this gap in disease knowledge through two independent, yet related research projects (Project 1 and Project 2). SAVSNET is piloting these two projects over its first three years (2008 to 2011).

\section{Collating laboratory results}

The first project involves national disease surveillance based on laboratory results. Its aim is to collect, collate and analyse data from veterinary diagnostic laboratories in the UK, and work towards publishing quarterly reports of diagnostic activity online.

During the pilot phase of this project from April to June 2009, 17,000 test results were collected from some 10,000 animals from four diagnostic laboratories (Biobest, Capital Diagnostics, NationWide Laboratories and Test-A-Pet), which kindly agreed to help develop and trial this part of the project. Ethical approval was obtained to collect the first two characters of the postcode of the practice submitting the sample, and this information will be used to give an indication of where the animal resides. One of the biggest challenges in this project is the disparate formats in which the data can be captured from each diagnostic laboratory and transferred to a secure server at the University of Liverpool. We are currently developing a methodology that allows the mapping of each format into a single common format for subsequent analysis using a 'metadatabase'. 
With existing SAVSNET funding, we aim to enrol approximately 12 laboratories in the UK during the remaining 12 months of the project. We estimate this could represent a combined data set of some 50,000 diagnostic test results per quarter. Enrolment of diagnostic laboratories involves the signing of a Data Transfer Agreement, designed to protect each laboratory's commercial interest. Details of individual test and/or total laboratory turnover may be commercially sensitive, and thus will be protected. Using the standardised data resulting from the developed meta-database, we will perform simple queries on the data collected, initially focused on pathogens associated with gastrointestinal disease in dogs and cats. We aim to publish quarterly summaries of these data on the SAVSNET website (www.liv. ac.uk/savsnet) at the end of this year, as well as developing focused articles on individual disease syndromes.

\section{Real-time surveillance}

Project 2 involves real-time syndromic surveillance in veterinary practice. Its aim is to develop a system that supports real-time, anonymised data collection at the end of each consultation with a consenting owner. To achieve this, we are collaborating with Vet Solutions, a leading supplier of veterinary practice management software. Vet Solutions has a 20 per cent market share, with its two programs (PremVet and RoboVet) being used in over 900 premises distributed across the UK.

Four types of data are routinely captured from the vet-visiting population during this project: routine signalment information such as the species, age, breed and sex of the animal; the reason the animal was presented to the vet (clinical text field); the treatment prescribed and dispensed, including dose and route of administration; and syndromic information

\section{TABLE 1: Summary statistics from the first three months of piloting SAVSNET Project 2}

Number of practices

Number of premises

Average number of consults per day

Total number of consults

Proportion of cats: dogs

Number of animals presenting for vomiting, diarrhoea

or vomiting and diarrhoea

Number of animals presenting for aggression

Number of animals presenting for pruritus
14
27
263
19,205
$1: 2.7$
357 cases in 7841 consultations ( 4.5 per cent)

25 cases in 7921 consultations ( 0.3 per cent) 65 cases in 2766 consultations ( 2.3 per cent)
These figures are included as exemplar outputs which SAVSNET will be able to achieve. The precise values should be interpreted with caution as at this stage of pilot development, values are sometimes based on relatively small numbers (a)

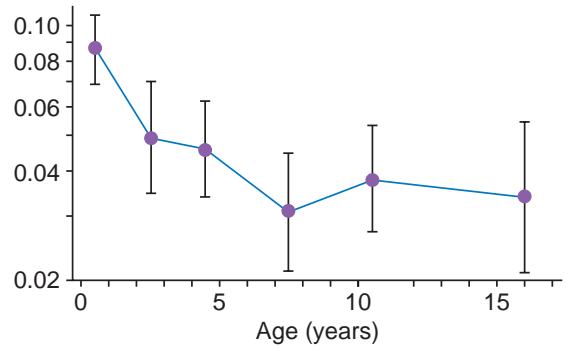

Cumulative incidence (per 1000)

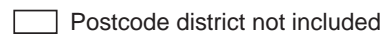

No observations

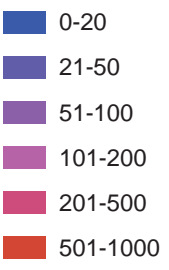

FIG 1: Examples of the types of SAVSNET's surveillance outputs. (a) Odds of acute gastrointestinal disease (vomiting and/or diarrhoea) in dogs plotted against midpoint of age category $( \pm 95$ per cent confidence interval). (b) Cumulative incidence of gastrointestinal disease in dogs in an area of the UK based on postcode districts during a one-month pilot study period. In both cases the precise values should be interpreted with caution as, at this stage of pilot development, values are sometimes based on relatively small numbers (b)

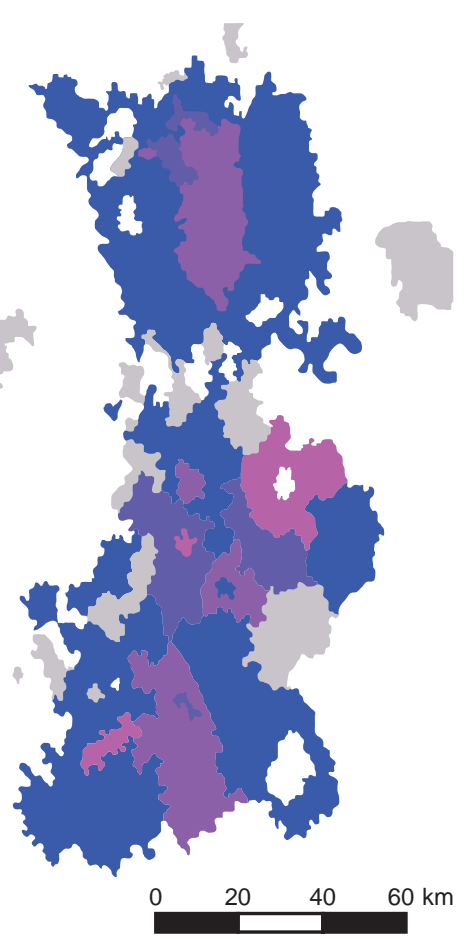

on each animal, captured by means of a simple questionnaire appended at the end of 'sick-animal' consultations. This questionnaire may be changed regularly to target a range of syndromes. This is a powerful tool, and to our knowledge a unique feature of the SAVSNET initiative, allowing us to capture structured crosssectional clinical data.

This project has been ethically approved by both the University of Liverpool Independent Ethics Committee and the Royal College of Veterinary Surgeons. This has allowed us to collect the owner's full postcode. An 'opt-out' policy has been implemented where any client can choose to exclude their animal's data from the study should they wish. Information on SAVSNET is available for the clients in each of the participating premises in the form of informative posters and an owner FAO booklet. SAVSNET's contact details are also available should any further information be required.

SAVSNET has just completed a threemonth pilot of this project in 32 veterinary premises throughout the UK, collecting information on diarrhoea and vomiting, aggression, and pruritus. Summary statistics from the first two months of this pilot are shown in Table 1 and Fig 1. To date, no ethical or practical concerns have arisen, and feedback indicates the project has been extremely well received by the participating practices. Further analysis will be published on the SAVSNET website in due course. With current funding, we now aim to collect data over a longer time period to further explore disease incidence, and identify spatial as well as temporal trends in the data.

\section{Funding and management}

The preliminary development of SAVSNET has been supported by a consortium of stakeholders (BSAVA, Dechra, Defra, Intervet/Schering-Plough Animal Health, Merial, NOAH, Novartis, Pfizer, University of Liverpool and Virbac) to develop the methodologies and collaborative links required for each project. We are extremely grateful for the foresight and trust demonstrated by our founder funders, whose initial altruistic funding has allowed us to pilot SAVSNET, demonstrating its potential as a powerful resource for the UK's veterinary and pet-owning population. The overarching activities of SAVSNET are managed by a group which meets annually and consists of all our collaborators and funders (see photograph on $\mathrm{p}$ 474). A Project 1 steering committee also meets annually and includes representatives of those laboratories that contribute data. In addition to veterinary surveillance, we are collaborating with colleagues at the University of Manchester who 


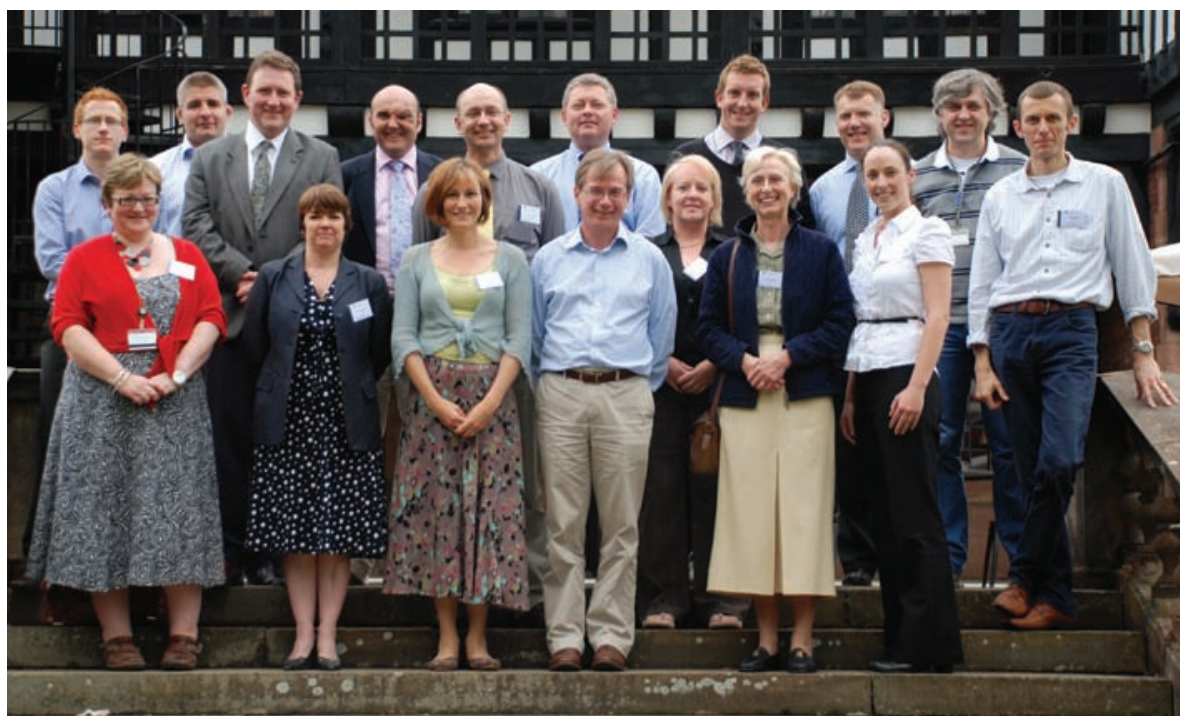

Delegates at the second SAVSNET management meeting, held July 2010. (back row from left): Kevin Whelan (Merial), Christian Setzkorn (University of Liverpool), John Helps (Intervet/Schering-Plough Animal Health), Callum Blair (Virbac), Andrew Frost (Defra), Richard Newton (AHT), Jonathan Lambert (Pfizer), Lloyd Richardson (Pfizer), Phil Jones (University of Liverpool) and Alan Radford (University of Liverpool). (front row from left): Susan Dawson (University of Liverpool), Carol Morgan (Dechra), Katie Dunn (BSAVA), Julian Bryan (Vet Solutions), Karen Coyne (University of Liverpool), Rosalind Gaskell (University of Liverpool) and Áine Tierney (University of Liverpool)

have developed 'NHS e-Lab' technology to support human epidemiology and healthcare planning - ensuring that the generic principles of informatics are reused (Ainsworth and Buchan 2009).

\section{Future plans}

Through these two coordinated surveillance projects involving laboratories and vets in practice, SAVSNET is hoping to provide a user-friendly approach to national companion animal disease surveillance in the UK. This is in line with one of the key recommendations of the Independent Inquiry into Dog Breeding in the UK, chaired by Professor Sir Patrick Bateson, which called for the establishment of an anonymous surveillance system to capture clinically useful data from vets in private practice (Bateson 2010). SAVSNET's first 24 months has proven the utility of both projects. We are extremely grateful for the help, patience and advice received from both the labs and veterinary practices that have contributed to our recent pilot studies, and without whose input SAVSNET would not be possible. We are currently exploring funding opportunities to allow us to provide more structured and nationally representative surveillance data to the veterinary community, along with clinical benchmarking data to practices taking part in Project 2. Our aim is to develop a national resource for companion animal surveillance, available under the tightly regulated conditions required to protect the anonymity of the data, to all approved scientists for ongoing academic studies. More information can be found at www. liv.ac.uk/savsnet or by e-mailing savsnet@ liverpool.ac.uk

\section{References}

AINSWORTH, J. \& BUCHAN, I. (2009) E-labs and work objects: towards digital health economies. In Communications Infrastructure. Systems and Applications in Europe. Eds R. Mehmood, E. Cerqueira, R. Piesiewicz, I. Chlamtazc. Springer. pp 206-216 BATESON, P. (2010) Independent Inquiry into Dog Breeding. http://breedinginquiry.files.wordpress. com/2010/01/final-dog-inquiry-120110.pdf. Accessed September 17, 2010

CAWC (2008) Companion Animal Welfare Surveillance. www.cawc.org.uk/080529.pdf. Accessed September 17,2010

CICADA (2010) CICADA - Companion Animal Disease Survey. www.cicadasurvey.co.uk. Accessed September 17, 2010

CRAWFORD, P. C., DUBOVI, E. J., CASTLEMAN, W. L., STEPHENSON, I., GIBBS, E. P., CHEN, L. \& OTHERS (2005) Transmission of equine influenza virus to dogs. Science 310, 482-485

DEFRA (2010) Dog and Cat Travel and Risk Information. www.defra.gov.uk/foodfarm/farmanimal/diseases/ vetsurveillance/dactari/index.htm. Accessed September 17, 2010

DEFRA/AHT/BEVA (2010) Equine Quarterly Disease Surveillance Reports. www.aht.org.uk/equine_disease. html. Accessed September 17, 2010

MURRAY, J. K., BROWNE, W. J., ROBERTS, M A WHITMARSH, A. \& GRUFFYDD-JONES, T. (2010) Number and ownership profiles of cats and dogs in the UK. Veterinary Record 166, 163-168

PROMED MAIL (2009) Influenza pandemic (H1N1) 2009, animal (36): USA (Colorado). www.promedmail. org. Accessed September 20, 2010

TAYLOR, L. H. LATHAM, S. M. \& WOOLHOUSE, M. E. (2001) Risk factors for human disease emergence. Philosophical Transactions of the Royal Society of London B 356, 983-989

VENOM (2010) Veterinary Nomenclature. www. venomcoding.org. Accessed September 17, 2010

VLA (2008) Veterinary Investigation Surveillance Report (VIDA). www.defra.gov.uk/vla/reports/rep_vida.htm. Accessed September 17, 2010

VMD (2010) Adverse reactions. www.vmd.gov.uk/ General/Adverse/adverse.htm. Accessed September 17, 2010

WESTGARTH, C., PINCHBECK, G. L., BRADSHAW, J. W., DAWSON, S., GASKELL, R. M. \& CHRISTLEY, R. M. (2007) Factors associated with dog ownership and contact with dogs in a UK community. BMC Veterinary Research 3, 5

doi:10.1136/vr.c5180 